have internationalism - which means an organless world, a world without nations, a world without the divisions into separate peoples. Neither can we have an isolation which would give us an organ seeking to function yet amputated from the whole. That is equally irrational. We must have a coöperation between the peoples of the world for the solution of the problems which are common to all the peoples of the world, a system not for the expansion of the territory of an empire, but for the occupation of undeveloped territory, for the formulation of international life and for the developing of plans by which, in the interests of all, the welfare of each would be cared for.

\title{
Allied Indebtedness to the United States
}

\author{
By John Foster Dulles \\ Former Financial Adviser for the Peace Conference
}

\section{$I^{\mathrm{N}}$} $\mathrm{N}$ any discussion of inter-Allied indebtedness, it is natural that our thoughts first turn to the question of whether the nations debtor to the United States are capable of obtaining the dollars wherewith to pay us. The capacity of the various debtor nations greatly varies. We can not rank equally France and Russia, or Great Britain and Poland. Let us first consider Great Britain as the debtor nation which has the greatest capacity for dollar payment. Analysis will indicate that it is perhaps possible for Great Britain to secure the necessary dollars to discharge her debt of some $\$ 4,500$,000,000 to us. She would do so in part by reselling American and other foreign securities, which her people still hold in large quantities. She would sell such of her own domestic securities as would command the confidence of the American investing public. She would perform services for us as shipper, banker, broker and insurer. She would export to us goods and limited quantities of gold. Payment in this way would be a long process, because in addition to her debt to our Treasury, Great Britain must take care of about $\$ 550,000,000$ of short term obligations held directly by the American public. But it is not beyond the realm of possi- bility that, given ample time and a moderate rate of interest, Great Britain could ultimately discharge her debt.

But Great Britain is in a unique position. No other nation has such equipment and international training for the collection of the dollars necessary to discharge a dollar obligation. The financial and economic situation of France is too shaken to permit her to undertake any important external payments, particularly as France has not been an important factor in international trade for many years and as she has not in existence, and could only with difficulty create, the organizations through which a foreign debt can most readily be paid; namely, organizations to supply service as shippers, insurers, bankers, et cetera, thus creating those invisible balances which are so important an element in the economic strength of Great Britain.

If we turn to the newly formed and re-created states such as Poland and the Serb-Croat-Slovene state, we find that it is exceedingly difficult for these States to finance even the most essential imports. The schemes which are being proposed to make this possible contemplate resort to the extreme expedient of their pledging to foreigners the very essentials of sovereignty, such as 
customs control and state monopolies. It seems doubtful that these states would be able to export goods or perform services sufficient to permit them to pay in dollars even the interest on their indebtedness to the Government of the United States.

It is obvious, therefore, that, taking our Allied debtors as a whole, these governments which now owe us in the aggregate approximately ten billion dollars of principal and one billion dollars of accrued interest, can not procure this amount of dollars for purposes of repayment.

This conclusion should not be disturbing to us. If these nations could devise ways and means of procuring the necessary dollars, the process would involve us in very serious economic disadvantages. Reverting to Great Britain, which has facilities we could with the least inconvenience utilize, we will see that to put Great Britain under pressure to pay in dollars would be to provide a powerful stimulus for Great Britain to constitute herself the world's carrier, the world's banker, the world's insurer, and one of the world's great exporters. Only by maintaining such a position could Great Britain effect the dollar payments which we contemplate. As the exertions of a capable debtor under pressure from his creditor are generally more effective than those of a complacent creditor, it is probable that the stimulus which we will thus supply will turn the scales against us in our own efforts to create a merchant marine and to establish banks and insurance companies for foreign business.

If countries other than Great Britain were capable of paying the dollars which they owe us, it would be only because they could sell their goods cheaper than the same goods could be sold by American industry.

The cardinal fact for us to bear in mind is that the ten billion dollars wherewith the Allies could pay their obligations can be secured only from America. The Allies must get them from us before they can pay them to us; and if the Allies do secure these dollars, it will be because the American public is buying foreign goods and using foreign services when otherwise they would be using American goods and American services. We can, therefore, readily reconcile ourselves to the Allied incapacity to pay us in dollars, as such payment would be largely at the expense of American industry, American capital and American labor, all of which could not but be very seriously affected by the American public utilizing on a vast scale foreign goods and foreign services.

If, therefore, the Allies owing dollars to the American Treasury probably can not secure the dollars wherewith to pay in full, and if it would be undesirable for us to permit them the opportunity to secure such a vast amount of dollars from the American public, we naturally turn to the alternative of an unconditional cancellation, in whole or in part, of the debts. Such a step would appear to me to be unfortunate, primarily because of its effect on the value of international obligations. Whether we should have contributed gratis the food, equipment, munitions, et cetera, now represented by the notes which we hold, is an academic question. We did not do so. On the contrary, the Allies agreed to give us a quid pro quo, and have delivered to us signed obligations to do so. If these obligations are now cancelled without our receiving any equivalent value therefor, it establishes a precedent which undermines every international obligation. The credit and borrowing power of every nation of the world will be affected, and a powerful impetus will be given to the demand of extremists that all 
war obligations, such as liberty bonds, should be wiped out.

It seems to me that there is an alternative between, on the one hand, a blind insistence upon receiving in dollars the full amount represented by the Allied notes, and, on the other hand, an unconditional cancellation in whole or in part of the obligations which we hold. The Allied nations may seem impecunious when we examine their capacity to pay dollars into the till of the United States Treasury. But they are none the less great and powerful nations. It would seem that only lack of resourcefulness and of statesmanship should lead us to the conclusion that there is no way in which these great nations can take action which will be of immense value to us even though not expressed in terms of gold dollars.

No one not in intimate touch with our national policies and the current diplomatic situation, could attempt to lay down any definite program covering this point. If we do have a definite national policy; if we do know what rôle we propose to play in the world's affairs, there are bound to be things which we want, things which will be of inestimable value to us, and things which it lies in the power of the Allied nations to give us.

I myself am not in a position to formulate any definite program as to what we want or to name the values in terms of which the Allies might discharge their obligations to us. Not as a definite program, but as illustrative only of my general thought, I would suggest the following:

(1) An analysis of the international trade situation should permit us to calculate roughly the extent to which we are prepared to use foreign goods and to use Allied services. This analysis will require us to take account of our tariff program. If it be our intention to protect American industry, it will limit our imports to goods not produced in this country on a scale sufficient to satisfy the American need. Such an analysis must also take into account our merchant marine policy. If it is to be our policy to require exports and imports to be carried in American bottoms, this will correspondingly reduce the amounts of dollars which Great Britain will be able to obtain. Once, however, our tariff policy and merchant marine policy are formulated, we can reach some rough estimate as to the value of foreign goods and the value of foreign services which Americans are likely to utilize in coming years. We can make some substantial addition to this sum on account of foreign securities which the American public may be expected to absorb.

From this resulting figure there should be deducted the value of exports which we will desire to make, for if our exports are to be maintained we must leave our debtors in a position to pay for them by imports and services to us. The balance-which I admit can only be calculated in the very roughest manner-will represent approximately our so-called "unfavorable balance," and there would seem to be no reason why we should not ask our debtors to make annual dollar payments into our Treasury equal to this sum. I suspect that these annuities will be relatively small if we intend to employ our merchant marine and to protect our domestic industries by a tariff wall; but whatever it is, it will be a sum which we ourselves have arrived at as representing both what Europe is capable of paying and what we are willing to let Europe get dollars enough to pay.

As this method of determining the annuities will of itself afford evidence of its reasonable character, it will constitute an immediate basis for credit. I see no reason why this sum can not be 
expressed in terms of dollar bonds of the respective debtor nations, with an appropriate interest rate and appropriate maturity, and the bonds be sold by the Treasury to the American public, either with or without the guaranty of this government. We would thus have secured some definite, tangible benefit, some relief to our taxpayers, which can not be secured so long as the Allied indebtedness is expressed in terms so vast and so vague that no one would have confidence in the possibility of dollar payment.

(2) The debt of the Allies to the United States did not arise out of normal conditions. It arose during war when there was an abnormal demand for American products for use in the prosecution of the war. We have already concluded that under normal conditions there can not be a counterflow of European products to a corresponding value. We can not, however, be assured that these normal conditions will always prevail. It is possible-although, I am glad to believe, quite improbable - that the United States might itself become engaged in war and might in this emergency require an abnormal flow of goods from Europe. If so, we would be in a situation analogous to that in which the Allies found themselves. Our own exports would cease and we would become huge importers. This would bring about a rapid depreciation of the dollar, and it would be very important for us to have facilities corresponding to those which we extended to the Allies to keep our currency at a parity, so as to permit us to continue purchasing abroad.

It will be recalled that a very substantial part of the sum which the Allies owe to us represents moneys advanced to keep their currency at a parity. I believe that wise statesmanship would require us to have in mind the possibility of a reversal of that situation, and that it would be a sound precaution to insure the continued purchasing power abroad of the dollar, by some agreement with the Allies to the effect that if we should hereafter require large quantities of goods from them, they would supply us their own currencies in sufficient amounts to keep the dollar at a parity.

(3) Anyone who has been at all familiar with political and economic developments of recent years, is aware that many of the nations which are debtors to us have secured from weaker nations agreements, sometimes expressed as formal treaties and sometimes as informal understandings, whereby they secure a preference in industrial and financial enterprises in these lesser states. In many cases this favored position has actually been obtained by means of the reloaning of funds obtained from our own government. It will be worth much to this nation if these understandings can be wiped out and if future financial pressure can be lessened through those nations which are debtors to us releasing their claims against lesser states. It is likewise important to us that this principle of "the open door" should find expression in the terms of mandates which, as now proposed, are in many cases very objectionable to this country.

(4) It is a matter of current knowledge that the United States has been endeavoring - though with but moderate success-to secure the utilization of possibly one or two cables which were taken from Germany after the war. We are doubtless entitled to these particular cables as a matter of right and without giving additional consideration therefor; but it would seem quite possible that there is much more which the Allies could properly be asked to do for us to improve our 
present very unsatisfactory situation as regards international communications.

(5) "A penny saved is a penny earned" says the proverb. If through coöperation with the Allies we can be enabled to save several hundred million dollars a year, that is as desirable as for them to pay us the same number of dollars. In fact, from an economic standpoint, it is much more desirable. The greatest expenditure in respect of which a saving is possible is expenditure for armament. It would seem quite appropriate that in any general discussion seeking to express in terms other than dollars the ways by which the American people may be benefited by the action of foreign nations, consideration should be given to the generalquestion of limitation of armament. If an understanding could be arrived at which would lead us to curtail our expenditure for armament, we would be quite justified in regarding that result as of the greatest financial value. I do not mean to say that we can crudely "buy off" other nations; but it would mark definite progress toward the realization of our national policy if some general contribution on our part would promote such an international understanding and good will as would permit us to effect a saving on armament and permit our debtors to make a similar saving. This, incidentally, would facilitate their meeting those obligations to us which would remain expressed in dollars.

The obligations of the Allies which we hold constitute a great trust to be held and employed by our government for the benefit of the American people. It is not a power to be abused, any more than it is a power to be abandoned. It is a power which should be used in the way which will in the long run produce the greatest gain to the American people. The greatest gain is not necessarily one which can be measured by the yard stick of dollars and cents; nor is a gain any less valuable because it involves benefit rather than burden to others.

If we would secure the greatest gain to the American people, let us first formulate a sound national policy. Then let us sit down in conference with the Allies and endeavor to secure their adhesion to international settlements which will render possible the carrying forward of our national policy. If such a settlement can be arrived at and if we regard their debts to us as in part discharged by the benefits which such a settlement would confer, this would not be an abandonment of our rights. Rather, we will have attained the highest form of realization.

\title{
Cancellation of European War Debts to the United States
}

\author{
By E. M. Patterson, Ph.D. \\ Professor of Economics, University of Pennsylvania
}

W AR obligations of European governments to the government of the United States, including principal and accumulated interest, total approximately $\$ 11,000,000,000$. In addition to this sum, American exporters, bankers and others are creditors on foreign account, chiefly private, to the amount of possibly $\$ 3,000,000,000$ to $\$ 4,000,000,000$. This latter sum is not directly involved in this discussion, but is indirectly affected. While some of 